\title{
ANTECEDENTS OF TURNOVER INTENTION: A META-ANALYSIS STUDY IN THE UNITED STATES
}

\section{Ahmet Hakan Ozkan', Meral Elci', Melisa Erdilek Karabay ${ }^{3}$, Hakan Kitapci ${ }^{4}$, Cinar Garip ${ }^{5}$}

1 Gebze Technical University, Institute of Social Sciences, Department of Business Management, Turkey, ORCID: 0000-0003-0348-754X, ahmetha@hotmail.com;

2 Gebze Technical University, Institute of Social Sciences, Department of Business Management, Turkey, ORCID: 0000-0002-0547-0250, emeral@gtu.edu.tr;

3 Marmara University, School of Banking and Insurance, Department of Insurance, Turkey, ORCID: 0000-0002-7531-5790, merdilek@marmara.edu.tr;

4 Gebze Technical University, Institute of Social Sciences, Department of Business Management, Turkey, ORCID: 0000-0001-6378-7240, kitapci@gtu.edu.tr;

5 Istanbul Aydin University, Anadolu Bil Vocational School, Department of Logistics, Turkey, ORCID: 0000-00022454-9175, cinarozkan@aydin.edu.tr.

\begin{abstract}
The purpose of this paper was to determine the direction and effect size of the relationships between turnover intention and its main antecedents in the United States. The main predictors of turnover intention are chosen as job satisfaction, organizational commitment and empowerment. The studies which are published between 1998 and 2018 are reviewed. ScienceDirect, Scopus, and ProQuest databases were searched and 2.356 studies are screened. The meta-analysis software package, Comprehensive Meta-analysis Software (CMA), was used for the meta-analysis. 101 studies were suitable and the three data sets are formed: first set included 312,261 subjects and 91 studies relating job satisfaction to turnover intention, the second set included 13,502 subjects and 29 studies relating organizational commitment to turnover intention, and the third set included 997 subjects and 5 studies relating empowerment to turnover intention. Each data was heterogeneous significantly and the random effects model was used. Publication bias is analyzed for each data set and no evidence of publication bias was detected. The results revealed that the overall relationship between turnover intention and the selected three constructs was negative and significant: the power of the job satisfaction's effect and organizational commitment's effect are almost the same (-.52), and the power of the empowerment's effect is weaker (-.22). Job satisfaction and organizational commitment have a large impact and empowerment has a small effect on turnover intention. The moderator analysis determined that type of industry and region are the moderators affecting the relationship between job satisfaction and turnover intention. The findings also provide guidance for the managers working in the United States who need to keep turnover under control.
\end{abstract}

Keywords: Job satisfaction, organizational commitment, empowerment, turnover intention.

JEL Classification: D23, J63.

APA Style Citation: Ozkan, A. H., Elci, M., Karabay, M. E., Kitapci, H., \& Garip, C. (2020). Antecedents of Turnover Intention: A Meta-analysis Study in the United States. E\&M Economics and Management, 23(1), 93-110. https://doi.org/10.15240/tul/001/2020-1-007

\section{Introduction}

In mature markets such as the markets of the United States, the organizations aim to form the best teams to be more effective in a competitive environment. But turnover is a threat to effective organizations. It is also an extra cost for the institutions. Therefore the managers try to keep turnover under control. But it is a challenging 
task because there is a lot of variables that influence turnover intention.

Job satisfaction, organizational commitment, and empowerment are chosen as the main antecedents of turnover intention. Meta-analysis studies showed that organizational commitment and job satisfaction are the strongest predictors of turnover intention (Tett \& Meyer, 1993; Choi \& Kim, 2016; Coomber \& Barriball, 2006; Kim \& Kao, 2014). Tett and Meyer (1993) reported that job satisfaction and turnover intention had the highest negative correlation among the other factors affecting turnover intention. The metaanalysis study of Pagilagan (2017) accepted organizational commitment and empowerment as the main antecedents of turnover intention.

Job satisfaction can be described as the positive development on the emotional state of the employees, which results from their job. Two Factor Theory of Frederick Herzberg (1966), put emphasis on the factors affecting job satisfaction and classified these factors in two groups: motivational factors, such as responsibility and achievement and hygiene factors, such as pay and supervision. The classification of satisfaction and dissatisfaction was prevalent in the 1950s (Weitz, 1952) and somehow these two groups were also related to this classification. The existence of motivational factors can lead to satisfaction and non-existence of hygiene factors can lead to dissatisfaction. Hygiene factors are also called extrinsic factors and motivational factors are also called intrinsic factors. Some researches focused on intrinsic and extrinsic job satisfaction and related each of them to turnover intention (Karsh et al., 2005; Brough \& Frame, 2004; Wang et al., 2012). This research included studies relating total job satisfaction to turnover intention.

Organizational commitment is the employee's adherence to the organization and it is a kind of psychological attachment (Meyer \& Herscovitch, 2001). Organizational commitment studies are improved with side-bet theory (Becker, 1960), and commitment is classified as occupational commitment and organizational commitment (Ritzer \& Trice, 1969). According to the three-component model, there are three kinds of organizational commitment: affective commitment, continuance commitment and normative commitment (Meyer \& Allen, 1991). The employees experiencing self-esteem, sense of belonging and safety, starts to get committed to that organization. If the company meets the requirements of the employee, then the employee deciding to quit will put these advantages in danger (Cho et al., 2009). Therefore organizational commitment plays a great role in quitting decisions.

Organizational commitment can be described as 'relative strength of an individual's identification and involvement in an organization' (Mowday et al., 1979, p. 226). Continuance commitment is about the fear of losing his job or position in the company, and normative commitment is about the norms and ethical rules of the individual which forces him to keep on working for that company. But affective commitment includes the factors that make an organization attractive to an employee. Continuance commitment and normative commitment affect staying as a member of the organization, but both of them are affected by the other factors which are not related to the organization. For this reason, the studies using affective commitment measurements are used together with other studies using organizational commitment measurements in this research.

Empowerment of employees includes a set of progressive and advanced human resources management practices transferring a considerable amount of power and decisionmaking rights from higher-level managers to lower-level employees (Kanter, 1977; Yin et al., 2019). Empowerment aims to increase the ability of employees to influence the outcomes. Some researches accepted empowerment as an important antecedent of turnover intention (Hauck et al., 2011; Thurston \& Glendon, 2018). Empowering the employees can reduce turnover intention (Martin, 2010). Thus empowerment is also chosen as a variable of this meta-analysis study. The aim of this paper, which uses meta-analysis method, is to determine the effect size of the correlations between job satisfaction and turnover intention, between organizational commitment and turnover intention, and between empowerment and turnover intention.

\section{Conceptual Relationships and Hypothesis Development}

Employees can be the most important assets of the organizations depending on the industry (Elci et al., 2018). Therefore turnover intention cannot be neglected by the managers. To see the big picture, previous research findings 
should be integrated quantitatively by using meta-analysis (Hedges \& Olkin, 1985). For example, some researchers used metaanalysis method to reveal factors that affect turnover (Irvine \& Evans, 1995; Mor Barak et al., 2001; Griffeth et al., 2000).

Humborstad and Perry (2011) related empowerment, organizational commitment and job satisfaction to turnover intention, and they found that these constructs have a negative and significant effect on turnover intention. The direction of the relationship between job satisfaction and turnover intention is mostly negative (Huang, 2006; Yang, 2008), and most researchers suggested that the direction of the relationship between organizational commitment and turnover intention is negative (Walsh, 2016; Wayne et al., 2006; Lentz \& Allen, 2009). Empowerment also influenced turnover intention negatively in some researches (Force, 2008; Keller, 2005; Okuyucu, 2014). Consequently, the hypotheses below can be tested:

H1: Job satisfaction has a negative effect on turnover intention.

H2: Organizational commitment has a negative effect on turnover intention.

H3: Empowerment has a negative effect on turnover intention.

Some academicians studied the relationship between job satisfaction and turnover intention among managers (Spector et al., 2007; Masuda et al., 2012). Another research showed that collar color affects the relationship between job satisfaction and turnover intention (Huang, 2011). Kumar et al. (2018) suggested that the impact of job level on the relationship between turnover intention and its antecedents depends on managerial support. Gong et al. (2018) revealed the moderating effect of managerial positions on the relationship between job satisfaction and turnover intention. These findings indicated that collar color can be a moderator of the relationships between turnover intention and its antecedents. Thus the hypotheses below will be tested:

H4a: Collar color is a moderator for the effect of job satisfaction on turnover intention.

H4b: Collar color is a moderator for the effect of organizational commitment on turnover intention.

H4c: Collar color is a moderator for the effect of empowerment on turnover intention.

The impact of the workplace on the relationship between job satisfaction and turnover intention was a significant concern of some researchers (Decker et al., 2009; Dickey et al., 2011). Occupational differences can also affect the relationship between job satisfaction and turnover intention (Frenkel et al., 2013). Alexe and Alexe (2018) claimed that a broader perspective is necessary and they revealed the impact of industrial differences on similar relationships. To be able to analyse the moderator effect of industry, a relatively huge data is necessary. The data of this study seems to be big enough to reveal the moderator effect of industry. Hence this meta-analysis study will analyse the moderator effect of industry on the surveyed relationships:

H5a: Type of industry is a moderator for the effect of job satisfaction on turnover intention.

H5b: Type of industry is a moderator for the effect of organizational commitment on turnover intention.

H5c: Type of industry is a moderator for the effect of job empowerment on turnover intention.

Doede (2017) has shown that race can be a predictor of the relationship between job satisfaction and turnover intention. It is suggested that the relationship between job satisfaction and turnover intention can be significantly different in different countries (Huang, 2011; Luu \& Hattrup, 2010). Guchait and Back (2016) collected data from the United States (US), South Korea and India, and surveyed the impact of the country on the relationship between organizational commitment and turnover intention. Alas and Edwards (2011) suggested that job satisfaction and organizational commitment are influenced by continents. Job satisfaction of nurses working in Africa are compared to the job satisfaction of the ones working in Europe and significant differences are revealed (Van der Hoef et al., 2012). Jones and Sloane (2009) suggested that regional differences affect the job satisfaction even in the same country. It is also suggested that organizational commitment may vary from a region to the other in the same country (Kokubun, 2017). In the light of these studies, the moderating effect of region on the surveyed relationships will be tested. In accordance with the purpose of testing the hypotheses below, the data which belong to the US should be classified into two groups, and the Southern US will be compared to Northern US to observe the impact of the region: 
H6a: Region is a moderator for the effect of job satisfaction on turnover intention.

H6b: Region is a moderator for the effect of organizational commitment on turnover intention.

H6c: Region is a moderator for the effect of empowerment on turnover intention.

\section{Methodology}

\subsection{Study Design}

In our study, the correlation between job satisfaction and turnover intention, the correlation between organizational commitment and turnover intention, and the correlation between empowerment and turnover intention are tested by using meta-analysis method and this meta-analysis study was designed and conducted according to Preferred Reporting Items for Systematic Reviews and MetaAnalyses (PRISMA) guidelines (Moher et al., 2009). The literature review was made in ProQuest, ScienceDirect and Scopus databases.

The inclusion criteria for this study can be defined as below:

- The researches were conducted in a 20 year period, which is between 1998 and 2018.

- The studies include correlation value, which is required for the meta-analysis of this study.

- The included correlation value should be computed by using total job satisfaction score and total turnover intention score.

- The construct job satisfaction should be overall job satisfaction, not a subscale.

- The data of the study should not be used twice.

\subsection{Search Strategy}

The data includes studies together with their samples from the US. The literature review was made in ProQuest, ScienceDirect, and Scopus databases. 212 studies from ScienceDirect, 1,141 studies from Proquest, and 1,003 studies from Scopus are reviewed. This study includes proceeding papers, articles published in nonrefereed and refereed journals, master theses and doctoral dissertations. "Organizational commitment", "empowerment", and "turnover intention" are the keywords used during the search for data.

All 2,356 abstracts were reviewed for inclusion in the meta-analysis. Of these, 1,759 ones were excluded because they did not relate the chosen constructs to turnover intention or to each other. After this process, 597 studies remained. 227 studies are excluded from these remaining studies, because 207 of them provided no correlation value between job satisfaction and turnover intention, 1 of them used the data and the results of a previous study which already existed, 3 studies correlated only the questions of the scale to turnover intention, 16 studies correlated only the subscales of job satisfaction to turnover intention. Among the remaining 370 studies, 269 of them were not conducted in the US and they are excluded. These 101 studies formed the final set, and they provided 91 correlation values for the relationship between job satisfaction and turnover intention, 29 correlation values for the relationship between organizational commitment and turnover intention, and 5 correlation values for the relationship between empowerment and turnover intention.

\subsection{Coding Process}

To design a data coding form one professor from the vocational school of health services, a quantitative research expert assisted the authors who performed the coding. The coding process aimed to extract the necessary information from the chosen studies. All the distinctive characteristics of the studies are written on the coding form, and it included the following components: References of the study, characteristics of the sampling, type of the measurement tool, correlation values, and sample size.

In the coding for the 101 studies, there was $98.7 \%$ agreement between the authors at the beginning, but authors reached a consensus for the items where disagreement existed. The quality evaluation of these studies was conducted using the quality rating scale of Zangaro and Soeken (2007). This scale includes 10 items which are used to score the study between 1 and 9 , the last item is the total score shown in table 1. A score between 1-4 means low quality, 5-7 means medium quality, 8 or 9 means high quality. Two researchers scored the studies, overall there was $99.8 \%$ rater agreement across the items. The study of Khanin et al. (2012) was scored as 9 by a researcher and 8 by the other researcher, and the average is taken as 8.5 (high). The studies of Diamond (2005), Dole and Schroeder (2001), 
Force (2008), Harris et al. (Harris, Brouer, \& Harris, 2009), Mattila (2006), Rode et al. (2007) and Tull (2004) are scored as 8 (high), the studies of Junak (2007), Laux et al. (2016), Osborne (2002) and Waul (2007) are scored as 7 (medium) and the rest of the studies are scored as 9 (high) by the authors. According to the quality analysis of the studies, $96.04 \%$ of the collected studies have high quality and only $3.96 \%$ of them have medium quality.

\section{Findings}

\subsection{Publication Bias and Heterogeneity}

Comprehensive Meta-analysis Software (CMA) is used to analyze the data provided by 52 articles, 46 doctoral dissertations, and 3 master theses. 3 data sets are used: 1st data set regarding the correlation coefficients regarding the relationship between job satisfaction and turnover intention, 2nd data set regarding the correlation coefficients regarding the relationship between organizational

\section{Fig. 1: Funnel plot of 1st data set (job satisfaction - turnover intention)}

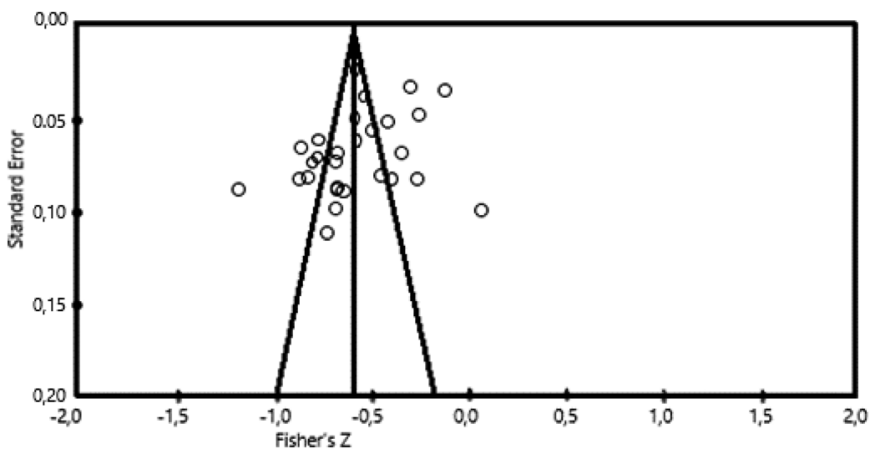

Source: own analyses

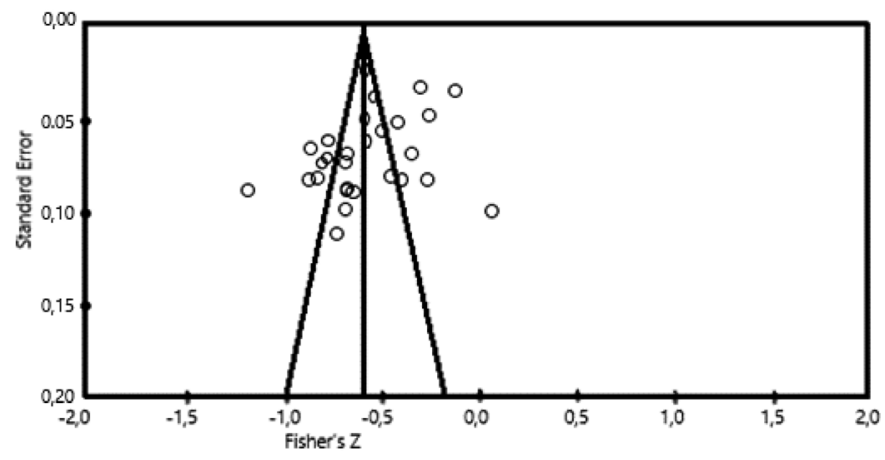


commitment and turnover intention, 3rd data set regarding the correlation coefficients regarding the relationship between empowerment and turnover intention.

Publication bias can be defined as lost data or as the possibility that all the researches related to the subject of the meta-analysis study, are not published. It is one of the significant limitations of meta-analysis studies. Funnel plot, which is the most common method, is used to observe publication bias. Asymmetrical distribution of the studies on the funnel plot is accepted as a sign of publication bias, and the funnel plot of the first data set regarding the relationship between job satisfaction and turnover intention shown in Fig. 1 included no evidence of publication bias.

Heterogeneity analysis results of the 1st data set suggested that this data is significantly heterogeneous at .01 level. $\mathrm{I}^{2}$ statistic of this data, which indicates the percentage of variability that is dues to the differences between studies compared to the variance of sampling, is $94.374 \%$. This value varies between $1-100 \%$ and higher values indicate higher heterogeneity. According to the test results, the heterogeneity of second data is significant at .01 level and $\mathrm{I}^{2}$ statistic of this data is $91.338 \%$. The funnel plot of the second data set regarding the relationship between organizational commitment and turnover intention is shown in Fig. 2. There is no evidence of publication bias in this funnel plot.

Analysis results showed that heterogeneity of the data including correlation values between empowerment and turnover intention is significant at the .01 level. $I^{2}$ statistic of third data is $83.47 \%$. All the data sets are heterogenous, therefore random effects model is used. Fig. 3 showed the funnel plot of the third data set, which indicated symmetrical distribution. To get accurate results, Duval and Tweedie's trim and fill test is carried out using the random effects model.

\section{Fig. 3: Funnel plot of 3rd data set (empowerment - turnover intention)}

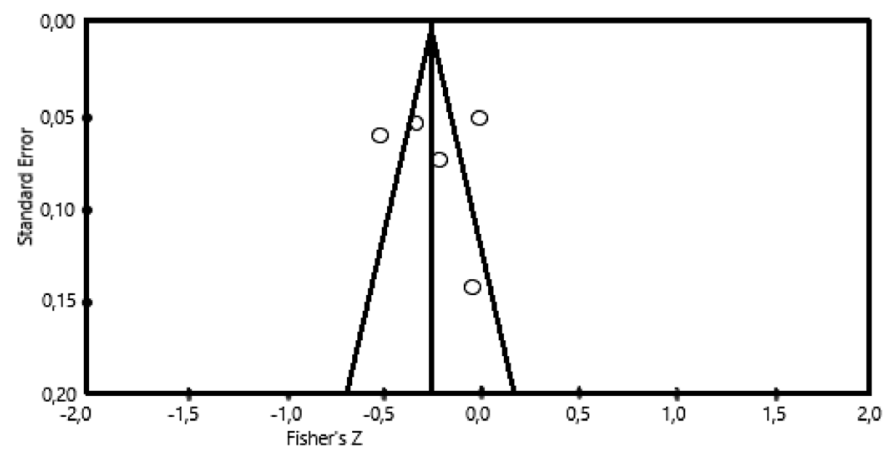

Source: own analyses

Tab. 1:

Duval and Tweedie's trim and fill test results of 1st data set (job satisfaction - turnover intention)

\begin{tabular}{l|c|c|c|c|c}
$\mathbf{N}=\mathbf{3 1 2 2 6 1}$ & & \multicolumn{3}{|c}{ Confidence interval (CI) } \\
\hline & $\begin{array}{c}\text { Trimmed } \\
\text { studies }\end{array}$ & $\begin{array}{c}\text { Point } \\
\text { estimate }\end{array}$ & Lower limit & Upper Limit & Q value \\
\hline Observed values & & -.54879 & -.56342 & -.53381 & $1,599.80561$ \\
\hline Adjusted values & 0 & -.54879 & -.56342 & -.53381 & $1,599.80561$ \\
\hline
\end{tabular}




\section{Tab. 2: Duval and Tweedie's trim and fill test results of 2nd data set (organizational commitment - turnover intention)}

\begin{tabular}{l|c|c|c|c|c}
\multicolumn{1}{c|}{$\mathbf{N = 1 3 5 0 2}$} & & \multicolumn{3}{|c}{ Confidence interval (Cl) } \\
\hline & $\begin{array}{c}\text { Trimmed } \\
\text { studies }\end{array}$ & $\begin{array}{c}\text { Point } \\
\text { estimate }\end{array}$ & Lower limit & Upper Limit & Q value \\
\hline Observed values & & -.54748 & -.59022 & -.50168 & 323.25876 \\
\hline Adjusted values & 0 & -.54748 & -.59022 & -.50168 & 323.25876 \\
\hline
\end{tabular}

In Tab. 1, the results of this test, which is carried out for the first data set, are given. According to the results, there is no sign of publication bias in this data set including the correlation values between job satisfaction and turnover intention. The artificial effect size which is formed to fix the impact of publication bias is compared to the observed effect size and no difference is detected. The reason for nonexistence of any difference is the symmetrical distribution of researches on both sides of the central line. As there is no evidence of lost data on both sides, no difference appeared between adjusted values and observed values.

In Tab. 2, the results of Duval and Tweedie's trim and fill test are indicated for second data set regarding the relationship between organizational commitment and turnover intention. These results indicated that there is no publication bias in second data set. The analysis results of Duval and Tweedies' trim and fill test which is carried out for third data set is shown in Tab. 3. No sign of publication bias is detected for the relationship between empowerment and turnover intention as there is no difference between the observed values and adjusted values.

\subsection{Findings Related to Effect Sizes}

The standard measure of the meta-analysis is the effect size, and it is used to determine the surveyed relationship's strength and direction (Borenstein et al., 2009). Pearson correlation coefficient values are collected to find the effect size. The effect size of the first data set is negative and $\mathrm{H} 1$ is accepted. The effect of job satisfaction on turnover intention is $-.55(r=-.549)$ and it reveals that job satisfaction has a large-level effect on turnover intention (see Cohen, 1988).

The effect size of the second data set is also negative and $\mathrm{H} 2$ is accepted. The effect of organizational commitment on turnover intention is $-.55(r=-.547)$ and it is almost the same with the effect of job satisfaction. This value also reveals that organizational commitment has a large-level effect on turnover intention (see Cohen, 1988). The effect of empowerment on turnover intention is negative and $\mathrm{H} 3$ is also confirmed. The effect size is computed as $-.22(r=-.215)$, which indicates that the power of this effect is small (see Cohen,1988).

Tab. 4 showed the analysis results of the first data. The impact of collar color is not significant, and the moderator analysis results did not support $\mathrm{H} 4 \mathrm{a}$, which asserted that the collar color is a moderating variable for the effect of job satisfaction on turnover intention $\left(Q_{b}=0.233, p>.05\right)$. According to the results of moderator analysis, type of industry is a moderator of the first data set $\left(Q_{b}=46.175\right.$, $\mathrm{p}<.01)$. This finding supported H5a.

\section{Tab. 3: Duval and Tweedie's trim and fill test results of 3rd data set (empowerment - turnover intention)}

\begin{tabular}{l|c|c|c|c|c}
\multicolumn{1}{c|}{$\mathbf{N}=997$} & & \multicolumn{3}{c}{ Confidence interval (CI) } \\
\hline & $\begin{array}{c}\text { Trimmed } \\
\text { studies }\end{array}$ & $\begin{array}{c}\text { Point } \\
\text { estimate }\end{array}$ & Lower limit & Upper Limit & Q value \\
\hline Observed values & & -.22075 & -.27936 & -.16050 & 24.19853 \\
\hline Adjusted values & 0 & -.22075 & -.27936 & -.16050 & 24.19853 \\
\hline
\end{tabular}




\section{Business Administration and Management}

\section{Tab. 4:}

Moderator analysis results of 1 st data set

\begin{tabular}{|c|c|c|c|c|c|c|c|}
\hline \multirow[b]{2}{*}{ Concepts } & \multirow[b]{2}{*}{ k } & \multirow[b]{2}{*}{$\mathbf{N}$} & \multirow[b]{2}{*}{$r$} & \multicolumn{2}{|c|}{$\mathrm{Cl}$} & \multirow[b]{2}{*}{$\mathbf{Q}$} & \multirow[b]{2}{*}{$\mathbf{Q}_{b}$} \\
\hline & & & & $\begin{array}{c}\text { Lower } \\
\text { limit }\end{array}$ & $\begin{array}{l}\text { Upper } \\
\text { limit }\end{array}$ & & \\
\hline Job satisfaction & 91 & 312,261 & $-.549^{*}$ & -.563 & -.534 & $1,599.81$ & \\
\hline Collar color & & & & & & & $0.233 \mathrm{~ns}$ \\
\hline White collar employees & 2 & 2,639 & -.516 & -.562 & -.467 & & \\
\hline Blue collar employees & 15 & 309,622 & -.594 & -.596 & -.592 & & \\
\hline Moderator (industry) & & & & & & & $46.175^{*}$ \\
\hline Civil transport & 2 & 300 & -.654 & -.741 & -.545 & & \\
\hline CRM & 2 & 218 & -.654 & -.742 & -.545 & & \\
\hline Education & 12 & 2,782 & -.581 & -.620 & -.539 & & \\
\hline Financial sector & 2 & 1,607 & -.636 & -.703 & -.559 & & \\
\hline Health & 26 & 291,251 & -.568 & -.591 & -.544 & & \\
\hline Information & 6 & 1,070 & -.535 & -.593 & -.471 & & \\
\hline Non-profit & 3 & 354 & -.475 & -.574 & -.361 & & \\
\hline Police & 2 & 669 & -.587 & -.665 & -.496 & & \\
\hline Public & 7 & 2,766 & -.514 & -.562 & -.462 & & \\
\hline Security & 3 & 1,029 & -.505 & -.580 & -.421 & & \\
\hline Sport & 2 & 624 & -.455 & -.551 & -.349 & & \\
\hline Tourism & 6 & 2,810 & -.425 & -.483 & -.364 & & \\
\hline Various & 18 & 6,781 & -.551 & -.581 & -.519 & & \\
\hline Moderator (region) & & & & & & & $12.056^{*}$ \\
\hline Northern US & 27 & 6,008 & -.524 & -.542 & -.506 & & \\
\hline Southern US & 32 & 9,681 & -.597 & -.610 & -.584 & & \\
\hline Other & 32 & 296,572 & -.595 & -.597 & -.592 & & \\
\hline
\end{tabular}

Source: own analyses

Note: ${ }^{*} p<.01$; ns: not significant.

Some studies are conducted in the Southern US and some of them are conducted in the Northern US. But first and second data included some studies which collected data from the whole US or which did not mention which part of the US is used to collect data. This group is called "other". Moderator analysis results of the first data set shown in Tab. 4 supported $\mathrm{H} 6 \mathrm{a}$ and region is a moderating variable for the effect of job satisfaction on turnover intention $\left(Q_{b}=12.056, p<.01\right)$.

Tab. 5 indicated the analysis results of the second data. The moderator analysis results did not support H4b and the moderator effect of collar color is not significant $\left(Q_{b}=0.531\right.$, $p>.05)$. There were not enough studies in the second data set to test $\mathrm{H} 5 \mathrm{~b}$. According to the moderator analysis results, the region is not a moderator for the second data set and $\mathrm{H} 6 \mathrm{~b}$ was not supported $\left(Q_{b}=0.494, p>.05\right)$.

The moderator analysis results of the third data set are shown in Tab. 6. This data set did not include adequate studies to test $\mathrm{H} 4 \mathrm{c}$ and $\mathrm{H} 5 \mathrm{c}$. The moderator analysis results did not support $\mathrm{H6c}$, which asserted that the region is a moderating variable for the effect of empowerment on turnover intention $\left(Q_{b}=0.083, p>.05\right)$. 


\begin{tabular}{l|c|c|c|c|c|c|c}
\multirow{2}{*}{ Concepts } & \multirow{2}{*}{$\mathbf{k}$} & $\mathbf{N}$ & $\mathbf{r}$ & \multicolumn{2}{c|}{$\mathbf{C l}$} & \multirow{2}{*}{$\mathbf{Q}$} & \multirow{2}{*}{$\mathbf{Q}_{\mathbf{b}}$} \\
\cline { 5 - 7 } & & & & Lower limit & Upper limit & & \\
\hline $\begin{array}{l}\text { Organizational } \\
\text { commitment }\end{array}$ & 29 & 13,502 & $-.547^{*}$ & -.590 & -.502 & 323.26 & \\
\hline Collar color & & & & & & & $0.531 \mathrm{~ns}$ \\
\hline $\begin{array}{l}\text { White collar } \\
\text { employees }\end{array}$ & 2 & 250 & -.611 & -.684 & -.527 & & \\
\hline $\begin{array}{l}\text { Blue collar } \\
\text { employees }\end{array}$ & 27 & 13,252 & -.532 & -.544 & -.519 & & \\
\hline Moderator (region) & & & & & & & $0.494 \mathrm{~ns}$ \\
\hline Northern US & 27 & 6,008 & -.497 & -.635 & -.328 & & \\
\hline Southern US & 32 & 9,681 & -.554 & -.485 & -.485 & & \\
\hline Other & 32 & 296,572 & -.553 & -.623 & -.474 & & \\
\hline
\end{tabular}

Note: ${ }^{*} p<.01$; ns: not significant.

\section{Tab. 6: Moderator analysis results of 3 rd data set}

\begin{tabular}{l|c|c|c|c|c|c|c}
\multirow{2}{*}{ Concepts } & \multirow{2}{*}{$\mathbf{k}$} & \multirow{2}{*}{$\mathbf{N}$} & $\mathbf{r}$ & \multicolumn{2}{|c|}{$\mathbf{C l}$} & \multirow{2}{*}{$\mathbf{Q}$} & \multirow{2}{*}{$\mathbf{Q}_{\mathbf{b}}$} \\
\cline { 5 - 6 } & & & & Lower limit & Upper limit & & \\
\hline Empowerment & 5 & 997 & $-.215^{*}$ & -.36 & -.06 & 24.19853 & \\
\hline Moderator (region) & & & & & & & $0.083 \mathrm{~ns}$ \\
\hline Northern US & 2 & 586 & -.248 & -.346 & -.145 & & \\
\hline Southern US & 3 & 413 & -.206 & -.279 & -.131 & & \\
\hline
\end{tabular}

Source: own analyses

Note: ${ }^{*} p<.01$; ns: not significant.

\section{Discussion and Conclusions}

The results of the meta-analysis showed that job satisfaction, organizational commitment, and empowerment had a negative impact on turnover intention. Job satisfaction and organizational commitment had a large impact on turnover intention and empowerment had a small impact on turnover intention. The effect size of job satisfaction and organizational commitment are almost the same. These results improved the findings of the previous studies (Tett \& Meyer, 1993; Choi \& Kim, 2016), which were in the health industry. Choi and Kim (2016) suggested that job satisfaction is the strongest predictor of turnover intention in the health industry. The findings of this study showed that organizational commitment and job satisfaction are both the strongest predictors of the turnover intention in the US. Such metaanalysis studies are very rare. To the best of our knowledge, any similar meta-analysis studies are not conducted to review the studies collecting data from the US.

Tab. 7 shows the analysis results of the hypotheses. 12 hypotheses would be tested, but 9 of them could be tested. $\mathrm{H} 1, \mathrm{H} 2, \mathrm{H} 3, \mathrm{H} 5 \mathrm{a}$, and $\mathrm{H} 6 \mathrm{a}$ are supported. $\mathrm{H} 4 \mathrm{a}, \mathrm{H} 4 \mathrm{~b}, \mathrm{H} 6 \mathrm{~b}$, and $\mathrm{H} 6 \mathrm{c}$ are rejected. The data was not suitable to test $\mathrm{H} 4 \mathrm{c}, \mathrm{H} 5 \mathrm{~b}$, and $\mathrm{H} 5 \mathrm{c}$.

Pagilagan (2017) accepted organizational commitment and empowerment as main factors that affect turnover intention. The findings 
Tab. 7: Summary of hypotheses test results

\begin{tabular}{c|c} 
Hypothesis & Test result \\
\hline $\mathrm{H} 1$ & Confirmed \\
\hline $\mathrm{H} 2$ & Confirmed \\
\hline $\mathrm{H} 3$ & Confirmed \\
\hline $\mathrm{H} 4 \mathrm{a}$ & Rejected \\
\hline $\mathrm{H} 4 \mathrm{~b}$ & Rejected \\
\hline $\mathrm{H} 4 \mathrm{c}$ & Not adequate data \\
\hline $\mathrm{H} 5 \mathrm{a}$ & Confirmed \\
\hline $\mathrm{H} 5 \mathrm{~b}$ & Not adequate data \\
\hline $\mathrm{H} 5 \mathrm{c}$ & Not adequate data \\
\hline $\mathrm{H} 6 \mathrm{a}$ & Confirmed \\
\hline $\mathrm{H} 6 \mathrm{~b}$ & Rejected \\
\hline $\mathrm{H} 6 \mathrm{c}$ & Rejected \\
\hline
\end{tabular}

Source: own analyses

of this study supported that organizational commitment is a strong antecedent of turnover intention, but the effect of empowerment is not as strong as organizational commitment. The effect size of organizational commitment is -.55 and the effect size of empowerment is -.22.

Different industries have different working conditions, and these changing conditions may affect how job satisfaction affects turnover intention. Estorninho (2013) determined that job satisfaction of the managers working in different industries can be significantly different. The results of the moderator analysis are in line with this study, and they indicated that industry is a moderating variable on the relationship between job satisfaction and turnover intention. The main limitation of analyzing the moderating effect of this variable was the size of data, and the other data sets did not include adequate studies for such an analysis testing the moderating effect of industry.

The region is important in the US. The temperature difference Northern US and Southern US is significantly high. Besides, the Southern US is affected by the hurricanes. If these conditions affect the quality of working life, they can also affect turnover intention. Because the direct effect of working life on turnover intention is significant (Celik \& Oz, 2011). The region has a moderating effect on the relationship between job satisfaction and turnover intention: Northern US has lower effect size comparing to Southern US. Anyway region is not a moderator of the relationship between organizational commitment and turnover intention and it is not a moderator of the relationship between empowerment and turnover intention. The reason for these results might be related to the structure of the constructs. The environment can influence job satisfaction significantly, for example, the police officers and employees of civil transport can be affected by the environment. But empowerment and organizational commitment are influenced by the organizations, rather than the environmental factors, such as climate.

Turnover intention is a threat to the institutions of the US, especially for the quality of labor-intensive companies' operations. The managers who are responsible to keep turnover under control should be aware of the factors affecting turnover intention. This study reveals the main predictors of turnover intention and the power of their effect. The managers can prepare their policy to keep turnover intention by using the knowledge provided by this meta-analysis.

\section{Limitations and Future Research}

The main aim of this meta-analysis study was reaching all the studies worldwide. Although 
the strategies were developed in order to review more studies, it was not possible to review some of them as all the studies were not in English. 1 study was in Korean, 1 study was in Chinese, 1 study was in German and 1 study was in Turkish. The authors could review the studies which were in Turkish and German, but they could not review the studies in Korean and Chinese, which may contribute to this meta-analysis. In the future, some other authors can conduct national meta-analysis researches by reviewing studies in different languages. For example, Choi and Kim (2016) conducted a meta-analysis study by reviewing the studies in English and in Korean to evaluate the relationship between job satisfaction and turnover intention. Collaborations between authors can open the way for the authors to conduct more advanced researches.

\section{References}

Alas, R., \& Edwards, V. (2011). Work-related attitudes in Asia and Europe: Institutional approach. Inzinerine Ekonomika-Engineering Economics, 22(1), 24-31. http://dx.doi. org/10.5755/j01.ee.22.1.215

Alexe, C.-G., \& Alexe, C.-M. (2018). Similarities and differentiations at the level of the industries in acquiring an organizational culture in innovation. Procedia Manufacturing, 22, 317-324. https://doi.org/10.1016/j.promfg. 2018.03.048

Becker, H. S. (1960). Notes on the concept of commitment. American Journal of Sociology, 66(1), 32-40. https://doi.org/10.1086/222820

Borenstein, M., Hedges, L. V., Higgins, J. P. T., \& Rothstein, H. R. (2009). Introduction to meta-analysis. Chichester: John Wiley \& Sons, Ltd. https://doi.org/10.1002/9780470743386

Brough, P., \& Frame, R. (2004). Predicting police job satisfaction and turnover intentions: The role of social support and police organisational variables. New Zealand Journal of Psychology, 33(1), 8-18.

Celik, D. A., \& Oz, E. U. (2011). The effects of emotional dissonance and quality of work life perceptions on absenteeism and turnover intentions among Turkish call center employees. Procedia-Social and Behavioral Sciences, 30, 2515-2519. https://doi.org/10.1016/j. sbspro.2011.10.491

Choi, S., E., \& Kim, S. D. (2016). A metaanalysis of the variables related to job satisfaction among Korean nurses. Contemporary Nurse, 52(4), 462-476. https://doi.org/10.1080/10376 178.2016.1221736

Cohen, J. (1988). Statistical power analysis for the behavioral sciences (2nd ed.). Hillsdale, NJ: Lawrence Erlbaum Associates. https://doi. org/10.1016/C2013-0-10517-X

Coomber, B., \& Barriball, K. L. (2007). Impact of job satisfaction components on intent to leave and turnover for hospital-based nurses: A review of the research literature. International Journal of Nursing Studies, 44(2), 297-314. https://doi.org/10.1016/j.jjnurstu.2006.02.004

Decker, F. H., Kojetin, L. D. H., \& Bercovitz, A. (2009). Intrinsic job satisfaction, overall satisfaction, and intention to leave the job among nursing assistants in nursing homes. The Gerontologist, 49(5), 596-610. https://doi. org/10.1093/geront/gnp051

Doede, M. (2017). Race as a predictor of job satisfaction and turnover in US nurses. Journal of Nursing Management, 25(3), 207-214. https://doi.org/10.1111/jonm.12460

Elci, M., Yildiz, B., \& Karabay, M. E. (2018). How burnout affects turnover intention? The conditional effects of subjective vitality and supervisor support. International Journal of Organizational Leadership, 7(1), 47-60. https://dx.doi.org/10.33844/ijol.2018.60233

Estorninho, R. (2013). Examining job satisfaction among real estate managers and travel agency managers in Algarve, Portugal (Doctoral dissertation). Northcentral University, Scottsdale.

Frenkel, S., Sanders, K., \& Bednall, T. (2013). Employee perceptions of management relations as influences on job satisfaction and quit intentions. Asia Pacific Journal of Management, 30, 7-29. https://doi.org/10.1007/ s10490-012-9290-z

Gong, Y., Xiong, J., Shu, X., \& Hu, X. (2018). Job satisfaction, turnover intention and work performance in Chinese family enterprises. Management International, 22(2), 84-95.

Griffeth, R. W., Hom, P. W., \& Gaertner, S. (2000). A meta-analysis of antecedents and correlates of employee turnover: update, moderator test, and research implications for the next millenium. Journal of Management, 26(3), 463-488. http://dx.doi.org/10.1016/ S0149-2063(00)00043-X

Guchait, P., \& Back, K. (2016). Three country study: impact of support on employee attitudes. The Service Industries Journal, 
36(7-8), 299-318. https://doi.org/10.1080/026 42069.2016.1186660

Hauck, A., Quinn Griffin, M. T., \& Fitzpatrick, J. J. (2011). Structural empowerment and anticipated turnover among critical care nurses. Journal of Nursing Management, 19(2), 269-276. http://dx.doi.org/10.1111/j.13652834.2011.01205.x

Hedges, L. V., \& Olkin, I. (1985). Statistical methods for meta-analysis. Orlando, FL: Academic Press. https://doi. org/10.1177/014662168701100108

Hellman, C. (1997). Job satisfaction and intent to leave. Journal of Social Psychology, 137(6), 677-689. http://dx.doi. org/10.1080/00224549709595491

Herzberg, F. (1966). Work and the nature of man. Cleveland, $\mathrm{OH}$ : World Publishing Co.

Huang, H. (2006). Understanding culinary arts workers. Journal of Foodservice Business Research, 9(2-3), 151-168. https://doi. org/10.1300/J369v09n02_09

Huang, T. (2011). Comparing motivating work characteristics, job satisfaction, and turnover intention of knowledge workers and blue-collar workers, and testing a structural model of the variables' relationships in China and Japan. The International Journal of Human Resource Management, 22(4), 924-944. https://doi.org/10.1080/09585192.2011.555134

Humborstad, S. I. W., \& Perry, C. (2011). Employee empowerment, job satisfaction and organizational commitment: An in-depth empirical investigation. Chinese Management Studies, 5(3), 325-344. https://doi. org/10.1108/17506141111163390

Irvine, D. M., \& Evans, M. G. (1995). Job satisfaction and turnover among nurses: Integrating research finding across studies. Nursing Research, 44(4), 246-253. http://dx.doi. org/10.1097/00006199-199507000-00010

Jones, R. J., \& Sloane, P. J. (2009). Regional differences in job satisfaction. Applied Economics, 41(8), 1019-1041. http://dx.doi. org/10.1080/00036840601019067

Kanter, R. M. (1977). Men and women of the Corporation. New York, NY: Basic Books.

Karsh, B., Booske, B. C., \& Sainfort, F. (2005). Job and organizational determinants of nursing home employee commitment, job satisfaction and intent to turnover. Ergonomics, 48(10), 1260-1281. https://doi. org/10.1080/00140130500197195
Kim, H., \& Kao, D. (2014). A meta-analysis of turnover intention predictors among U.S. child welfare workers. Children and Youth Services Review, 47(3), 214-223. https://doi. org/10.1016/j.childyouth.2014.09.015

Kokubun, K. (2017). Regional differences in the organizational commitment-rewards relationship in Vietnam. Journal of Management and Sustainability, 7(3), 22-37. https://doi. org/10.5539/jms.v7n3p22

Kumar, M., Jauhari, H., Rastogi, A., \& Sivakumar, S. (2018). Managerial support for development and turnover intention: Roles of organizational support, work engagement and job satisfaction. Journal of Organizational Change Management, 31(1), 135-153. https://doi.org/10.1108/JOCM-06-2017-0232

Lynn, M., \& Redman, R. (2005). Faces of the nursing shortage: influences on staff nurses' intentions to leave their positions or nursing. Journal of Nursing Administration, 35(5), 264-270. https://doi.org/10.1097/00005110200505000-00010

Martin, T. (2010). Formal and informal power, Access to work empowerment structures, and intent to stay (Master Thesis). Ball State University, Muncie.

Masuda, A. D., Poelmans, S. A. Y., Allen, T. D., Spector, P. E., Lapierre, L. M., Cooper, C. L., ... Moreno-Velazquez, I. (2012). Flexible work arrangements availability and their relationship with work-to-family conflict, job satisfaction, and turnover intentions: A comparison of three country clusters. Applied Psychology: An International Review, 61(1), 1-29. https://doi. org/10.1111/j.1464-0597.2011.00453.x

Meyer, J. P., \& Allen, N. J. (1991). A three-component conceptualization of organizational commitment. Human Resources Management Review, 1(1), 61-89. https://doi. org/10.1016/1053-4822(91)90011-Z

Meyer, J. P., \& Herscovitch, L. (2001). Commitment in the workplace: toward a general model. Human Resources Management Review, 11(3), 299-326. https:// doi.org/10.1016/S1053-4822(00)00053-X

Moher, D., Liberati, A., Tetzlaff, J., \& Altman, D. G. (2009). Preferred reporting items for systematic reviews and meta-analyses: The PRISMA statement. Annals of Internal Medicine, 151(4), 264-269. https://doi.org/10.1371/ journal.pmed.1000097

Mor Barak, M. E., Nissly, J. A., \& Levin, A. (2001). Antecedents to retention and turnover 
among child welfare, social work, and other human service employees: What can we learn from past research? A review and metanalysis. The Social Service Review, 75(4), 625-661. https://doi.org/10.1086/323166

Mowday, R. T., Steers, R. M., \& Porter, L. W. (1979). The measurement of organizational commitment. Journal of Vocational Behavior, 14(2), 224-247. https://doi.org/10.1016/00018791(79)90072-1

Pagilagan, H. (2017). Factors that affect turnover intention of registered nurses in the acute hospital: A meta-analysis from 2006-2016 (Doctoral project 71). http://scholarworks.sjsu.edu/etd_doctoral/71

Ritzer, G., \& Trice, H. M. (1969). An empirical study of Howard Becker's side-bet theory. Social Forces, 47(4), 475-479. https:// doi.org/10.2307/2574537

Spector, P. E., Allen, T. D., Poelmans, S. A. Y., Lapierre, L. M., Cooper, C. L., O'Driscoll, M. P., ... Widerszal-Bazyl, M. (2007). Crossnational differences in relationships of work demands, job satisfaction, and turnover intentions with work-family conflict. Personnel Psychology, 60(2), 805-835. https://doi. org/10.1111/j.1744-6570.2007.00092.x

Tett, R. P., \& Meyer, J. P. (1993). Job satisfaction, organizational commitment, turnover intention, and turnover: path analyses based on meta-analytic findings. Personnel Psychology, 46, 259-293. https://doi. org/10.1111/j.1744-6570.1993.tb00874.x

Thurston, E., \& Glendon, A. I. (2018). Association of risk exposure, organizational identification, and empowerment, with safety participation, intention to quit, and absenteeism. Safety Science, 105, 212-221. https://doi. org/10.1016/j.ssci.2018.02.012

Van der Hoef, M., Mbazzi, F. B., \& Verhoeven, C. (2012). Job conditions, job satisfaction, somatic complaints and burnout among East African nurses. Journal of Clinical Nursing, 21(11-12), 1763-1775. https://doi. org/10.1111/j.1365-2702.2011.03995.x

Wang, Y., Yang, C., \& Wang, K. (2012) Comparing public and private employees' job satisfaction and turnover. Public Personnel Management, 41(3), 557-573. https://doi. org/10.1177/009102601204100310

Weitz, J. (1952). A Neglected Concept in the Study of Job Satisfaction. Personnel Psychology, 5(3), 201-205. https://doi. org/10.1111/j.1744-6570.1952.tb01012.x
Zangaro, G. A., \& Soeken, K. L. (2007). A meta-analysis of studies of nurses' job satisfaction. Research in Nursing \& Health, 30(4), 445-58. https://doi.org/10.1002/ nur.20202

\section{List of Meta-analysis}

Acker, G. M. (2018). Self-care practices among social workers: do they predict job satisfaction and turnover intention? Social Work in Mental Health, 16(6), 710-724. https://doi.or g/10.1080/15332985.2018.1494082

Agada, C. N. (2013). The relationship between job satisfaction and intent to turnover among software engineers in the informtion technology industry (Doctoral dissertation). Capella University, Minneapolis.

Alarcon, G. M., \& Edwards, J. M. (2011). The relationship of engagement, job satisfaction and turnover intentions. Stress and Health, 27(3), 294-298. https://doi.org/10.1002/smi.1365

Andrews, M. C., Kacmar, K. M., \& Kacmar, C. (2014). The mediational effect of regulatory focus on the relationships between mindfulness and job satisfaction and turnover intentions. Career Development International, 19(5), 494507. https://doi.org/10.1108/CDI-02-2014-0018

Baird, J. (2006). The intent to leave: an investigation of empowerment mechanisms, job satisfaction, and organizational commitment among technical college employees (Doctoral dissertation). Capella University, Minneapolis.

Baranik, L. E., Roling, E. A., \& Eby, L. T. (2010). Why does mentoring work? The role of perceived organizational support. Journal of Vocational Behavior, 76(3), 366-373. https:// doi.org/10.1016/j.jvb.2009.07.004

Bolima, D. C. (2015). The relationship between caring leadership, nursing job satisfaction, and turnover intentions (Doctoral dissertation). Grand Canyon University, Phoenix.

Boone, D. L. (2003). Job satisfaction and intent to turnover of mental health direct care professionals working in residential settings (Doctoral dissertation). Argosy University, Atlanta.

Brown, A. B. (2012). Civility, job satisfaction, and intentions to quit (Doctoral dissertation). University of Cincinnati, Cincinnati.

Buttner, E. H., Lowe, K. B., \& Billings-Harris, L. (2012). An empirical test of diversity climate dimensionality and relative effects on employee of color outcomes. Journal of Business Ethics, 110, 247-258. http://dx.doi.org/10.1007/ s10551-011-1179-0 
Carlson, J. R., Carlson, D. S., Zivnuska, S., \& Harris, R. B. (2017). Applying the job demands resources model to understand technology as a predictor of turnover intentions. Computers in Human Behaviour, 77, 317-325. http://dx.doi. org/10.1016/j.chb.2017.09.009

Cho, S., Johanson, M. M., \& Guchait, P. (2009). Employees intent to leave: A comparison of determinants of intent to leave versus intent to stay. International Journal of Hospitality Management, 28(3), 347-381. https://doi.org/10.1016/j.ijhm.2008.10.007

Clemens, E. V. (2008). A leader-member exchange approach to understanding school counselors' roles, job satisfaction, and turnover intentions (Doctoral dissertation). University of North Carolina, Greensboro.

Cronley, C., \& Kim, Y. K. (2017). Intentions to turnover: Testing the moderated effects of organizational culture, as mediated by job satisfaction, within the Salvation Army. Leadership \& Organization Development Journal, 38(2), 194-209. https://doi. org/10.1108/LODJ-10-2015-0227

Cunningham, G. B., \& Sagas, M. (2004). Examining the main and interactive effects of deepand surface-level diversity on job satisfaction and organizational turnover intentions. Organizational Analysis, 12(3), 319-341.

Daniel, D. (2013). Correlates of job satisfaction and turnover intentions among mental health professionals (Doctoral dissertation). Walden University, Minneapolis.

Davis, V. A. (2006). Relationship among subjective workplace fit perceptions, job satisfaction, organizational citizenship behaviour, organizational commitment, and turnover intentions (Doctoral dissertation). Alliant International University, Alhambra.

D'Costa, A. (2017). Research study measuring employee engagement, job satisfaction, and intention to turnover in universities across the United States (Doctoral dissertation). Southern Illinois University Carbondale, Carbondale.

Deconinck, J. B., \& Johnson, J. T. (2009). The effects of perceived supervisor support, perceived organizational support, and organizational justice on turnover among salespeople. Journal of Personal Selling and Sales Management, 29(4), 333-350. https://doi.org/10.2753/PSS0885-3134290403

Diamond, L. K. (2005). Antecedents and consequences of emotional dissonance:
Understanding the relationships among personality, emotional dissonance, job satisfaction, intention to quit and job performance (Doctoral dissertation). University of South Florida, Tampa.

Dion, M. J. (2006). The impact of workplace incivility and occupational stress on the job satisfaction and turnover intention of acute care nurses (Doctoral dissertation). University of Connecticut, Storrs.

Dole, C., \& Schroeder, R. G. (2001). The impact of various factors on the personality, job satisfaction and turnover intentions of professional accountants. Managerial Auditing Journal, 16(4), 234-245. https://doi. org/10.1108/02686900110389188

Douglas, G. P. (2015). Predicting teacher turnover intentions through morale and job satisfaction: A quantitative study (Doctoral dissertation). Northcentral University, Scottsdale.

Fazio, J., Gong, B., Sims, R., \& Yurova, Y. (2017). The role of affective commitment in the relationship between social support and turnover intention. Management Decision, 55(3), 512-525. http://dx.doi.org/10.1108/MD05-2016-0338

Force, L. M. (2008). The incluence of casual attribution on work exhaustion and turnover intention of traditional discipline engineers in the United States (Doctoral dissertation). Nova Eastern University, Fort Lauderdale.

Frost, J. A. (2006). Predictors of job satisfaction and turnover intention in police organizations: A procedural approach (Doctoral dissertation). University of Illinois at Chicago, Chicago.

Gaither, C. A., Kahaleh, A. A., Doucette, W. R., Mott, D. A., Pederson, C. A., \& Schommer, J. C. (2008). A modified model of pharmacists' job stress: The role of organizational, extra-role, and individual factors on workrelated outcomes. Research in Social and Administrative Pharmacy, 4(3), 231-243. https://doi.org/10.1016/j.sapharm.2008.04.001

Grigg, S. H. (2009). The impact of job satisfaction, organizational commitment, and intent to leave on employee retention: An investigation within the child care industry (Doctoral dissertation). Capella University, Minneapolis.

Han, G., \& Jekel, M. (2011). The mediating role of job satisfaction between leader-member exchange and turnover intentions. Journal of 
Nursing Management, 19(1), 41-49. https://doi. org/10.1111/j.1365-2834.2010.01184.x

Harden, G., Boakye, K. G., \& Ryan, S. (2018). Turnover intention of technology professionals: A social exchange theory perspective. Journal of Computer Information Systems, 58(4), 291-300. https://doi.org/10.10 80/08874417.2016.1236356

Harris, J. J., Harris, R. B., \& Brouer, R. L. (2009). LMX and subordinate political skill: Direct and interactive effects on turnover intentions and job satisfaction. Journal of Applied Social Psychology, 39(10), 2373-2395. https://doi. org/10.1111/j.1559-1816.2009.00530.x

Harris, J. J., Wheeler, A. R., \& Kacmar, K. M. (2009). Leader-member exchange and empowerment: Direct and interactive effects on job satisfaction, turnover intentions, and performance. The Leadership Quarterly, 20(3), 371-382. https://doi.org/10.1016/j. leaqua.2009.03.006

Hartmann, N. N., \& Rutherford, B. N. (2015). Psychological contract breach's antecedents and outcomes in salespeople: The roles of psychological climate, job attitudes, and turnover intention. Industrial Marketing Management, 51, 158-170. https://doi. org/10.1016/j.indmarman.2015.07.017

Hazell, K. W. (2010). Job stress, burnout, job satisfaction, and intention to leave among registered nurses employed in hospital settings in the State of Florida (Doctoral dissertation). Lynn University, Boca Raton.

Henryhand, H. J. (2009). The effect of employee recognition and employee engagement on job satisfaction and intent to leave in the public sector (Doctoral dissertation). Capella University, Minneapolis.

Hong, J. J. (2009). The influence of perceived workplace spirituality on job satisfaction, intention to leave, and emotional exhaustion among community mental health center workers (Doctoral dissertation). University of Kansas, Lawrence.

Huey, J. D. (2003). The influence of family responsive practices on job satisfaction, organizational commitment, and intentions to turnover for working women with children (Doctoral dissertation). Columbia University, New York.

Jang, J., \& George, R. T. (2012). Understanding the influence of polychronicity on job satisfaction and turnover intention: A study of non-supervisory hotel employees. International
Journal of Hospitality Management, 31(2), 588-595. https://doi.org/10.1016/j.jhm.2011.08.004

Jang, J., \& Kandampully, J. (2018). Reducing employee turnover intention through servant leadership in the restaurant context: A mediation study of affective organizational commitment. International Journal of Hospitality \& Tourism Administration, 19(2), 125-141. https://doi.org/10.1080/15256480.2017.1305310

Jawahar, I. M., \& Hemmasi, P. (2006). Perceived organizational support for women's advancement and turnover intentions: The mediating role of job and employer satisfaction. Women in ManagementReview, 21(8),643-661. https://doi.org/10.1108/09649420610712036

Junak, J. A. (2007). Effects of perceived organizational support on turnover intention through job satisfaction and organizational commitment (Doctoral dissertation). Roosevelt University, Chicago.

Keebler, D. W. (2012). Organizational commitment, job satisfaction, and turnover intention: A study of the baby boomer generation (Doctoral dissertation). Regent University, Virginia Beach.

Keller, K. M. (2005). Being different: $A$ study of relational demography and the influence of individual and team characteristics (Master thesis). University of Maryland, College Park.

Khanin, D., Turel, O., Raj, V., \& Mahto, R. V. (2012). How to Increase Job Satisfaction and Reduce Turnover Intentions in the Family Firm: The Family-Business Embeddedness Perspective. Family Business Review, 25(4), 391-408. https://doi.org/10.1016/j. indmarman.2015.07.017

Kim, M., \& Beehr, T. A. (2018). Empowering leadership: leading people to be present throgh affective organizational commitment? The International Journal of Human Resource Management. https://doi.org/10.1080/0958519 2.2018.1424017

Kim, W. G., Leong, J. K., \& Lee, Y. (2005). Effect of service orientation on jobsatisfaction, organizational commitment, and intention of leaving in a casual dining chain restaurant. Hospitality Management, 24(2), 171-193. https://doi.org/10.1016/j.ijhm.2004.05.004

King-Lawrence, S. (2003). An examination of the relationship between job satisfaction and intention to leave among specialty sales representatives in a major pharmaceutical organization (Doctoral dissertation). Capella University, Minneapolis. 
Kirsh, M. C. (2011). Job satisfaction and intention to quit: a study of health care employees (Master thesis). Northern Illinois University, DeKalb.

Laux, D., Luse, A., \& Mennecke, B. E. (2016). Collaboration, connectedness and community: An examination of the factors influencing student persistence in virtual communities. Computer in Human Behaviour, 57, 452-464. https://doi.org/10.1016/j.chb.2015.12.046

Lee, H. (2000). An empirical study of organizational justice as a mediator of the relationships among leader-member exchange and job satisfaction, organizational commitment, and turnover intentions in the lodging industry (Doctoral dissertation). Virginia Polytechnic Institute and State University, Blacksburg.

Lee, Y. H., \& Chelladurai, P. (2018). Emotional intelligence, emotional labor, coach burnout, job satisfaction, and turnover intention in sport leadership. European Sport Management Quarterly, 18(4), 393-412. https://doi.org/10.1080/16184742.2017.1406971

Lee, W., Joo, H., \& Johnson, W. W. (2009). The effect of participatory management on internal stress, overall job satisfaction, and turnover intention among Federal probation officers. Federal Probation, 73(1), 33-47.

Lentz, E., \& Allen, T. D. (2009). The role of mentoring others in the career plateauing phenomenon. Group \& Organization Management, 34(3), 358-384. https://doi. org/10.1177/1059601109334027

Levin, A. G. (2003). Profession at risk: Why are so many workers leaving the field of child welfare? Exploring the relationship between diversity, inclusion, supervisory support, stress, job satisfaction and intention to leave among public child welfare workers (Doctoral dissertation). University of Southern California, Los Angeles.

Lin, N., Jang, J., \& Roberts, K. R. (2018). Are employees with higher organization-based self-esteem less likely to quit? A moderated mediation model. International Journal of Hospitality Management, 73, 116-124. https://doi.org/10.1016/j.ijhm.2018.01.021

Liou, S. (2007). The relationships between collectivist orientation, perception of practice environment, organizational commitment, and intention to leave current job among Asian nurses working in the U.S. (Doctoral dissertation). The University of Texas at Austin, Austin.
Liu, Y. S. (2010). The relationship among work support, organizational commitment and citizenship behaviour of part-time employees in the restaurant industry (Master thesis). Oklahoma State University, Stillwater.

Lu, A. C. C., \& Gursoy, D. (2016). Impact of job burnout on satisfaction and turnover intention: do generational differences matter? Journal of Hospitality \& Tourism Research, 40(2), 210-235. https://doi. org/10.1177/1096348013495696

Lu, L., Lu, A. C. C., Gursoy, D., \& Neale, N. R. (2016). Work engagement, job satisfaction, and turnover intentions. A comparison between supervisors and line-level employees. International Journal of Contemporary Hospitality Management, 28(4), 737-761. https://doi.org/10.1108/IJCHM-07-2014-0360

Luthans, F., Zhu, W., \&Avolio, B. J. (2006). The impact of efficacy on work attitudes across cultures. Journal of World Business, 41(2), 121-132. https://doi.org/10.1016/j.jwb.2005.09.003

Luu, L., \& Hattrup, K. (2010). An investigation of country differences in the relationship between job satisfaction and turnover intentions. Applied H. R. M. Research, 12(1), 17-39.

Martin, N. K., Sass, D. A., \& Schmitt, T. A. (2012). Teacher efficacy in student engagement, instructional management, student stressors, and burnout: A theoretical model using in-class variables to predict teachers' intent-to-leave. Teaching and Teacher Education, 28(4), 546-559. https://doi.org/10.1016/j.tate.2011.12.003

Mathieu, C., \& Babiak, P. (2016). Corporate psychopathy and abusive supervision: Their influence on employees' job satisfaction and turnover intentions. Personality and Individual Differences, 91, 102-106. https://doi. org/10.1016/j.paid.2015.12.002

Mattila, R. R. (2006). The relationship between burnout, job satisfaction, turnover intention, and organizational commitment in IT workers (Doctoral dissertation). Capella University, Minneapolis.

Mattingly, J. W. (2007). A study of relationships of school climate, school culture, teacher efficacy, collective efficacy, teacher job satisfaction and intent to turnover in the context of year-round education calendars (Master thesis). University of Louisville, Louisville.

Matz, A. K., Wells, J. B., Minor, K. I., \& Angel, E. (2012). Predictors of turnover intention among staff in juvenile correctional 
facilities: The relevance of job satisfaction and organizational commitment. Youth Violence and Juvenile Justice, 11(2), 115-131. https://doi.org/10.1177/1541204012460873

McCarthy, C. J., Lambert, R. G., Crowe, E. W., \& McCarthy, C. J. (2010). Coping, stress, and job satisfaction as predictors of advanced placement statistics teachers' intention to leave the field. NASSP Bulletin, 94(4), 306-326. https://doi.org/10.1177/0192636511403262

McDowell, S. S. (2015). Client-inflicted workplace violence, burnout, job satisfaction, and turnover intention: A comparative analysis between institution-based and home-based direct care paraprofessionals (Doctoral dissertation). Howard University, Washington.

McNabb, N. S. (2009). The daily floggings will continue until morale improves: An examination of the relationships among organizational justice, job satisfaction, organizational commitment and intention to turnover (Doctoral dissertation). University of Oklahoma, Norman.

McNall, L. A., Masuda, A. D., \& Nicklin, J. M. (2009). Flexible work arrangements, job satisfaction, and turnover intentions: The mediating role of work-to-family enrichment. The Journal of Psychology, 144(1), 61-81. https://doi.org/10.1080/00223980903356073

Meloncon, B. F. (2011). An examination of the Professional challenges, job satisfaction, and intention to leave the profession of urban elementary special education teachers (Doctoral dissertation). Texas A\&M University, College Station.

Miller, P. E. (2007). The relationship between job satisfaction and intention to leave: A study of hospice nurses in a for profit corporation (Doctoral dissertation). Capella University, Minneapolis.

Mitterer, D. (2017). Servant leadership and its effect on employee job satisfaction and turnover intent (Doctoral dissertation). Walden University, Minneapolis.

Mor Barak, M. E., Levin, A., Nissly, J. A., \& Lane, C. J. (2006). Why do they leave? Modeling child welfare workers' turnover intentions. Children and Youth Services Review, 28(5), 548-577. https://doi.org/10.1016/j.childyouth.2005.06.003

Nayak, N. (2002). Job satisfaction and organizational commitment as factors of turnover intention of IRS procurement employees (Doctoral dissertation). Walden University, Minneapolis.
Needham, M. R. (2018). Relationship between servant leadership characteristics and turnover in fast-casual restaurants (Doctoral dissertation). Walden University, Minneapolis.

O'Connor, J. (2018). The impact of job satisfaction on the turnover intent of executive level central office administrators in Texas public school districts: A quantitative study of work related constructs. Education Sciences, 8(2), 69. https://doi.org/10.3390/educsci8020069

Okuyucu, A. A. (2014). Perceived underemployment among the foreign-born: Its outcomes and the moderating role of psychological empowerment and perceived organizational support (Master thesis). San Jose University, San Jose.

Osborne, J. S. (2002). Components of empowerment an how they differentially relte to employee job satisfaction, organizational commitment and intent to leave the job (Doctoral dissertation). Vanderbilt University, Nashville.

Patel, J. M. (2015). Predicting employees' work exhaustion, job satisfaction, and, turnover intention: The role of informated job resources and personal resources (Doctoral dissertation). University of Memphis, Memphis.

Pugh, G. L. (2016). Job satisfaction and turnover intent among hospital social workers in the United States. Social Work in Health Care, 55(7), 485-502. https://doi.org/10.1080/009813 89.2016.1186133

Regev, E. (1998). A study of job satisfaction, age, marital status, education, experience, perceived job alternatives, job search behaviour and intention to leave the job (Doctoral dissertation). Nova Southeastern University, Fort Lauderdale.

Ro, H., \& Lee, J. (2017). Call center employees' intent to quit: Examination of job engagement and role clarity. Journal of Quality Assurance in Hospitality \& Tourism, 18(4), 531-543. https://doi:10.1080/152800 8X.2017.1292163

Rode, J. C., Rehg, M. T., Near, J. P., \& Underhill, J. R. (2007). The effect of work/family conflict on intention to quit: The mediating roles of job and life satisfaction. Applied Research in Quality of Life, 2(2), 65-82. https://doi:10.1007/ s11482-007-9030-6

Ross, K. L. (2017). Pregnancy and work: A mixed-methods study of job satisfaction and turnover intentions during a first pregnancy (Doctoral dissertation). University of Maryland, College Park. 
Schwepker, C. H. (2001). Ethical climate's relationship to job satisfaction, organizational commitment, and turnover intention in the salesforce. Journal of Business Research, 54(1), 39-52. https://doi.org/10.1016/S01482963(00)00125-9

Shontz, J. Z. (2016). A different type of project crashing: Sources of occupational stress within the project management profession and the influence of occupational stress on the job satisfaction and turnover intention of project managers (Doctoral dissertation). Sullivan University, Louisville.

Smith, T. D. (2018). An assessment of safety climate, job satisfaction and turnover intention relationships using a national sample of workers from the USA. International Journal of Occupational Safety and Ergonomics, 24(1), 27-34. https://doi. org/10.1080/10803548.2016.1268446

Smith, V. A. (2010). Job satisfaction and intentions to quit of marriage and family therapists: A comparison of work settings (Doctoral dissertation). Purdue University, West Lafayette.

Tull, T. A. (2004). The relationship between perceived level of synergystic supervision received, job satisfaction, and intention to turnover of new professionals in student affairs administration (Doctoral dissertation). Florida State University, Tallahassee.

Udechukwu, I. I. (2006). The relationship between job satisfaction, organizational commitment, intentions to quit, and perceived alternative employment in the assessment of employee turnover: A study of correctional officers (Doctoral dissertation). Nova Southeastern University, Fort Lauderdale.

Valentine, S., Godkin, L., Fleischman, G. M., \& Kidwell, R. (2011). Corporate ethical values, group creativity, job satisfaction and turnover intention: The impact of work context on work response. Journal of Business Ethics, 98(3), 353372. https://doi.org/10.1007/s10551-010-0554-6

Walsh, K. (2016) Applying career concepts to strengthen the work attitudes of service professionals, The Service Industries Journal, 36(1-2), 58-79. https://doi.org/10.1080/026420 69.2016.1155115

Waul, A. R. (2007). An empirical study of leader member Exchange (LMX) on consultants' attitudes and behaviours towards their parent organization (Doctoral dissertation). Touro University California, Vallejo.

Wayne, H. W., Randel, A. E., \& Stevens, J. (2006). The role of identity and work-family support in work-family enrichment and its workrelated consequences. Journal of Vocational Behaviour, 69(3), 445-461. https://doi. org/10.1016/j.jvb.2006.07.002

Westlund, S. G. (2007). Retaining talent: Assessing relationships among project leadership styles, software developer job satisfaction, and turnover intentions (Doctoral dissertation). Capella University, Minneapolis.

Wilson, A. A. (2006). The lone wolf phenomenon: The impact of commitment and performance on turnover intention in sales (Doctoral dissertation). San Diego Alliant International University, San Diego.

Wright, K. B., Abendschein, B., Wombacher, K., O'Connor, M., Hoffman, M., Dempsey, ... Shelton, A. (2014). Work-related communication technology use outside of regular work hours and work life conflict: The influence of communication technologies on perceived work life conflict, burnout, job satisfaction, and turnover intentions. Management Communication Quarterly, 28(4), 507-530. https://doi.org/10.1177/0893318914533332

Yanchus, N. J., Periard, D., Moore, S. C., Carle, A. C., \& Osatuke, K. (2015). Predictors of job satisfaction and turnover intention in VHA mental health employees: A comparison between psychiatrists, psychologists, social workers, and mental health nurses. Human Service Organizations: Management, Leadership and Governance, 39(3), 219-244. https://doi.org/10.1080/23303131.2015.1014953

Yang, J. (2008). Effect of newcomer socialisation on organisational commitment, job satisfaction, and turnover intention in the hotel industry. The Service Industries Journal, 28(4), 429-443. https://doi. org/10.1080/02642060801917430

Young, C. A., \& Corsun, D. L. (2010). Burned! The impact of work aspects, injury, and job satisfaction on unionized cooks' intention to leave the cooking occupation. Journal of Hospitality \& Tourism Research, 34(1), 78-102. https://doi.org/10.1177/1096348009349816 